\title{
A study on expression methods for structural aesthetics in modern fashion design \\ - Focus on the architectural characteristics of Santiago Calatrava -
}

\author{
Yeonji Lee and Sohee $\mathrm{Um}^{+}$ \\ Dept. of Fashion Design, Gangneung-Wonju National University, Korea

\section{현대 구조적 패션디자인에 나타난 구조미의 표현방식에 대한 연구 - 산티아고 칼라뜨라바의 건축특성을 중심으로 -} \\ 이 연 지·엄 소 희 ${ }^{\dagger}$ \\ 강릉원주대학교 패션디자인학과
}

\begin{abstract}
The structural aesthetics of architecture are becoming an inspirational source for many fashion designers and have been reborn in structural fashion. This study planned to analyze the method of expression of structural aesthetics expressed in modern structural fashion design and the construction method to maximize such an effect on the basis of the construction characteristic of Santiago Calatrava as the representative architect of the structural aesthetic. According to the study, the structural aesthetics expressed in modern structural fashion design are as follows: 1) The symbolical formative aesthetic expressed by symbolical inference and analyzation; 2) the dynamic beauty of physic expressed by visual emphasis and dynamics; and 3) the asymmetric beauty of symmetry expressed by metastasis toward the boundary between balance and imbalance. In addition, to maximize structural aesthetics, we used repetition and a progressive technique based on rhythm, asymmetry, and incision-based variances, such as balance, polygon flux, and inference, and analyzation-based distortion as the structuring principle. The following expression methods for maximizing structural aesthetics were found: 1) symbolical and structural exaggeration of appearance; 2) detail technique expansion and material property diversification; and 3) the three-dimensional transformation of structure and shell expression. Structural fashion design was found to have maximized structural aesthetics by using such expression methods to secure artistic esthetics, destroy existing shapes and patterns, and create unique shapes.
\end{abstract}

Keywords: structural aesthetics(구조미), maximization(극대화), Santiago Calatrava(산티아고 칼라뜨라바), architectural characteristics(건축적 특성)

\section{Introduction}

21세기에 들어서면서 인문학, 사회과학, 자연과
학, 예술학 등 다양한 학문분야 간의 교류가 활발하 게 이루어지고 있다. 패션분야 또한 예외는 아니며, 특히 인간의 생활과 가장 밀접한 관계의 건축과 패

Received 22 May 2015, revised 29 June 2015, accepted 14 July 2015.

+ Corresponding author (simple8401@gwnu.ac.kr) 
션은 외부로부터 인간을 보호하고, 3 차원적인 구조 의 조형물로 예술성을 표현한다는 점에서 근본 요 소를 공유하고 있다. 이러한 상호 연관성으로 건축 과 패션의 각 요소들은 서로 영향을 주고받으며 새 로운 방향으로 나아가고 있으며, 건축에서 나타나는 구조적인 조형미는 많은 패션디자이너들에게 영감 의 근원이 되어 조형적인 패션으로 새롭게 재탄생 되고 있다.

현대 건축은 기능성과 합리성이 주목적이었던 과 거의 단순한 건축형태에서 벗어나 많은 건축가들이 다양한 예술적 모티브를 근원으로 한 작품을 추구 하고 있다. 특히 렌조 피아노(Renzo Piano), 리차드 로저스(Richard Rogers), 노만 포스터(Norman Foster) 는 구조적인 건축의 대가로 꼽히며, 이들의 계보를 잇는 건축가로는 영국의 니콜라스 그림쇼(Nicholas Grimshaw)와 스페인의 산티아고 칼라뜨라바(Santiago Calatrava)를 들 수 있다. 그 중 산티아고 칼라뜨라바 는 구조미학의 대표적인 건축가로, 자연의 생명체나 인체 등을 모티브로 하여 건축의 구조적인 형태와 공간의 특성을 표현한다. 이는 인체를 디자인의 근 원으로 한다는 점이 다른 건축가들과 차별화 되며, 칼라뜨라바의 디자인 세계는 패션디자이너의 관심
사와 일맥상통한다고 할 수 있다. 뿐만 아니라 예술 성과 기술성의 상호 통일적 관점을 지향하는 동시 대의 문화-사회적 패러다임 속에서 현대 구조적 패션디자인과 동향을 이루기에 패션분야와 비교연 구의 가치가 있다.

건축의 조형성과 관련된 선행연구를 살펴보면 Park (2012)은 건축과의 연관성을 중심으로 패션에 표현 된 기능주의적 미니멀리즘을 연구하였고, $\operatorname{Kim}(2009)$ 은 건축적 조형성이 반영된 현대 패션의 특성을 연 구하였다. $\operatorname{Im}(2015), \operatorname{Sohn}(2013), \mathrm{Cho}(2011), \mathrm{Na}(2010)$, $\operatorname{Shin}(2008), \operatorname{Sung}(2005)$ 는 건축가의 작품에 나타난 조형적 특성을 응용하여 의상을 제작하였다. 이처럼 건축의 외적인 조형성과 조형적 특성에 관한 선행 연구 사례들은 많지만, 그러한 조형성을 나타내기 위해서 어떠한 방법을 사용하였는지에 대한 실질적 연구 사례는 부족한 실정이다. 따라서 건축과 패션 의 상호 표현 가능성을 확대하기 위해서는 건축과 패션의 조형미를 강조하기 위한 표현방식에 관한 연 구가 필요할 것이다.

본 연구의 목적은 기능과 형태라는 복합적 요소 를 단순하지만, 독창적인 구조와 공간의 특성으로 표현하는 산티아고 칼라뜨라바의 건축특성을 중심

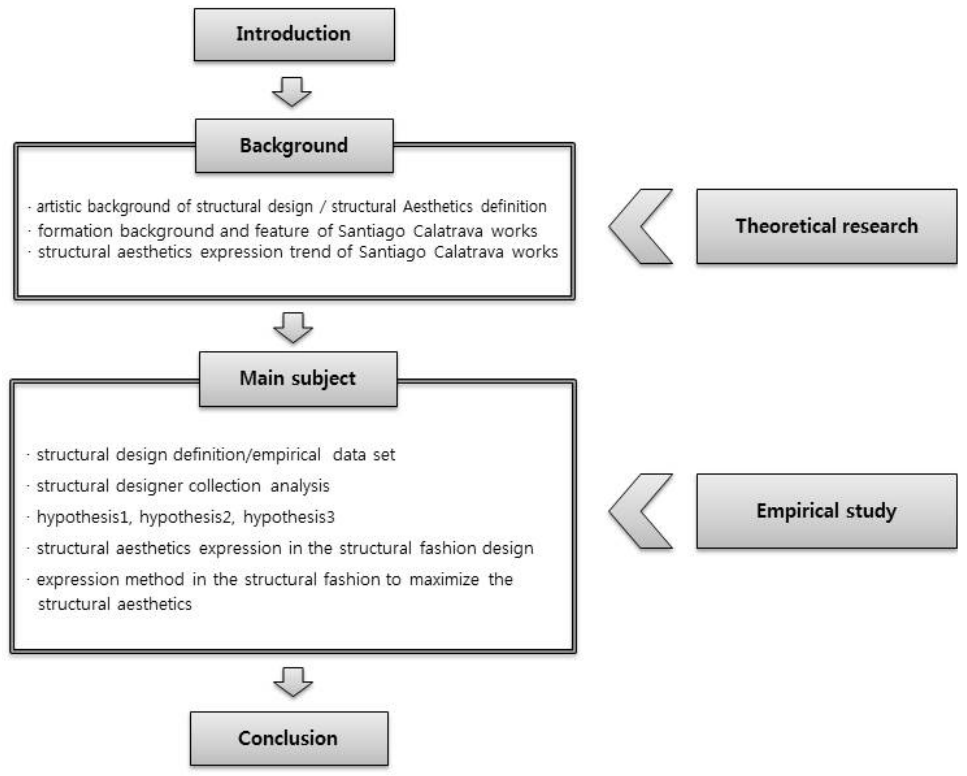

〈Fig. 1〉 The study organization chart 
으로 구조미 표현방법과 그러한 효과를 위해 사용 된 구축방식을 고찰함으로써 현대 구조적 패션디자 인에 표현된 구조미의 표현방법과 그러한 효과를 극대화하기 위한 표현방식을 분석하고자 한다.

연구내용은 첫째, 근대 이후 구조적 디자인의 예 술적 배경분석과 구조미에 대한 용어를 정의한다. 또한 칼라뜨라바 건축의 작품형성배경, 작품세계를 통해 칼라뜨라바 작품의 독자성과 구조미의 표현방 법을 연구하고, 그러한 구조미 표현을 위해 사용된 디테일, 표현과 은유방식, 역학적 효과분석 등 구축 방법을 고찰한다. 또한 이론적 배경에서 구조미에 대한 용어를 정의한다. 둘째, 현대패션에 나타난 구 조미 표현 분석에 사용할 패션사례의 실증적 자료 를 구조적 디자인으로 가상 설정하고, 연구에 사용 할 구조적 디자인에 대한 용어정의와 연구의 틀을 만든다. 셋째, 칼라뜨라바의 작품분석 자료와 구조 적 패션디자인 작품의 실증적 자료를 통해 현대 구 조적 패션디자인에 나타난 구조미의 표현특성과 구 조미의 극대화를 위한 표현방식을 분석한다.

연구 자료는 관련 문헌과 선행 연구, 인터넷 자료 를 통해 이론적 배경을 고찰하였고, 실증적 자료는 www.style.com에서 컬렉션 사진자료를 추출하였다. 산티아고 칼라뜨라바의 작품 87점과 패션작품 640 점의 사진자료를 분석하였다. 이상의 연구 절차를 정리하면〈Fig. 1〉의 연구 구성도와 같다.

\section{Background}

\section{The artistic background of structural design}

19세기는 고대 그리스 건축이래 전통적 시대양식 에서 탈피하여 근대건축 및 현대건축의 사조로 전 환되는 과도기적 시기였다. 산업혁명 이후 대량 생 산으로 강철이나 유리, 콘크리트라는 새로운 재료들 이 건축의 주재료로 사용되면서 건물의 외형과 건 설비용의 변화를 가져왔고, 기존의 건축 기술보다 더 발전하여 고층 건물을 건축하는 기술까지 나아 가게 된다. 이러한 기계화에 따라 박람회가 이루어 지게 되고, 영국 런던 박람회에서 죠셉 팩스톤이 설 계한 조립식 유리로만 만들어진 '수정궁'과 철제로 만 이루어진 에펠의 '에펠탑'은 프랑스 파리 박람회 를 통해 건축 기술이 얼마나 발전하였는지 확인할
수 있게 해주었다. 그 영향으로 건축에서 기계미와 구조미를 추구하는 양식인 구조주의 양식이 형성 되었다.

기계화로 인한 대량생산은 사람들에게 활력을 주 었지만, 19 세기 말 영국 출신의 화가이자 공예가 윌 리엄 모리스와 몇몇 예술가, 수공업자들은 진정한 노동의 즐거움을 상실한 시대의 변혁을 주장하였다. 산업혁명이 가져온 예술의 전통적인 기술력의 소실 로 인한 예술의 기계화, 양산화로 기계만능주의의 팽배를 반발한 것이다. 여러 분야에서 전통적 '수공 업’만이 가진 아름다움의 회복을 위해 이러한 모임 들은 점차 확대되어 '미술공예운동(Arts and Crafts Movement)'을 하게 된다. 기계문명이라는 거대한 시대흐름을 무시하였다는 점에서 시대를 역행한 듯 한 이러한 움직임은 결국 시장경제의 원리로 대량 생산에 밀려나게 되었다. 그러나 예리한 문제점 제 기와 수공예품의 질적 향상과 조화를 추구한 이론 적 주장과 양식은 초기 모더니즘의 아르누보 양식 에 영향을 주었을 뿐만 아니라, 근대 디자인 운동의 시발점이 되었다.

1 차 세계대전 이후 보다 적극적인 산업과 예술의 만남이 이루어지게 되는데, 그 새로운 변혁을 이룬 것이 바로 ‘바우하우스'이다. 1919년 독일의 건축가 인 발터 그로피우스(Walter Gropius)에 의해 설립된 바우하우스는 건축가, 조각가, 화가들은 공예로 모 두 돌아갈 것을 주장하며, 공업과 예술의 복합적인 교육을 하였으며, 예술과 기술의 통합이라는 연구 성과를 평가받기 시작했다. 바우하우스의 영향을 받 은 '데스틸(De Stijl)' 단체는 네덜란드 화가 피에트 몬드리안(Pieter Cornelis Mondriaan)의 주도로 단순 히 회화에만 국한된 것이 아닌 예술과 건축이 통합 된 선진문화예술을 선보였다.

모더니즘 시대에 바우하우스는 몬드리안의 회화 처럼 강한 원색 대비를 통한 비례를 보여 주는 깔끔 하고 세련된 기하학적인 기능주의에 관심을 보이게 되 었고, 이것은 후에 '국제주의 양식(International Style)' 형성의 계기가 되었다. 순수한 볼륨의 강조, 대칭이 아닌 경제성에 의한 규칙성, 부가된 장식에 반대되 는 재료의 본질적 우아함의 표현을 미학적 원리로 한 국제주의 양식은 2 차 세계대전 이후 사회변동에 따른 변혁을 시도하는 미국에서 큰 인기를 가졌으 
나, 단순한 박스 형태가 자본주의와 획일성의 표상 이며 진부하다는 비난을 받게 된다. 그 결과, 모더니 즘의 경직성의 개념으로부터 벗어나 다양성, 자율 성, 대중성, 개성을 중시하고, 과거의 장식을 다시 차용하는 포스트모더니즘의 시대가 시작되었다. 사 용자는 건축가가 만들어 놓은 양식을 선택할 수밖 에 없었던 모더니즘 시대와는 달리 사용자가 원하 는 건축가와 직접 소통할 수 있는 건축인 포스트모 더니즘 건축이 탄생된 것이다.

이처럼 급속한 산업발달과 건축가들의 실험 정 신, 미의식의 변화 속에서 선진국들의 자본을 바탕 으로 한 하이테크 건축이 생겨났다. 하이테크 건축 의 명칭은 1960 년대 후반, Team-4가 디자인한 릴라 이언스 콘트롤즈사(Reliance Controls Factory)에 최 초로 붙여졌으며, 그 후 영국을 중심으로 한 노만 포 스터, 리차드 로저스, 렌조 피아노 등의 건축가들이 하 이테크 건축의 주도적 역할을 수행하였다 $(\mathrm{Na}, 2008)$. 하이테크는 아름답게 조형된 혹은 매끈한 표현 자 체에서 산업적이고 기계 미학적인 형태를 만들어 냄으로써 완성물의 수준을 높여갔다.

하이테크 건축은 공학기술을 구조적 표현의 측면 에서 적절히 각색하고 응용하여 '첨단처럼 보이게' 하는 '첨단 이미지'를 창출하기 시작했는데, 첨단 이미지는 부재의 노출, 현휘가 높은 물성 사용, 구조 기술력 과시 등을 통해 재생산되었고, 첨단 이미지 를 기초로 ‘소비를 위한 대중성의 구현' 의도 역시 포장되었다. 즉, 이들 건축가들은 생산성을 대중성 의 개념으로 해석한다는 포괄적 개념에 덧붙여 건 축을 하나의 소비대상으로 인식(Kam, 2009)하였다. 이처럼 하이테크는 구조를 첨단이미지 혹은 공학이 미지로 바꾸어 표현하는 형식주의 구조미학을 대표 한다고 볼 수 있다. 탈착개념(plug-in pod)으로 인한 건물 수명의 연장, 기술로 인한 환경의 조절, 구조적 경제성 등을 목표로 한 하이테크 건축 역시 점차 경 제성이나 실질적 효용성에 대한 목표와는 별개로 오히려 공학적이며 기계적인 미학과 구조미 만이 강조되는 경향의 결과를 가져왔다.

이후 현대건축은 구조적 표현을 중심으로 구조체 계 만을 강조하는 방식과 다른 구조체계와 외피, 세 부요소 등과 통합의 관점으로 구축하는 방식으로 구별된다. 최근에는 구조에 있어서 최소부재로 최대
구조물을 구축하고자 하는 경향과 함께 특수구조의 공학적 가능성을 극대화함으로써 미학적 특성을 더 욱 강조하는 경향으로 발전하고 있다. 따라서 최근 의 구조디자이너들은 구조 미학적 특성을 부각시키 기 위해 단순히 구조미를 강조하는 수준을 넘어 인 체의 구성 원리 등으로부터 구조미의 모델을 인용 하는 등 디자인 개념을 함축적으로 표현하는 방향 으로 진화하고 있지만, 오히려 단순한 형태를 창조 하는 성과를 보여주고 있다. 이러한 구조디자이너들 중 독특한 구조미를 보여주는 건축가 산티아고 칼 라뜨라바는 기능과 형태미라는 복합적 요소를 가장 단순하면서도 독창적으로 표현함으로써 구조미학 의 대표적 건축가로 평가를 받고 있다.

\section{The formation background and feature of Santiago Calatrava works}

1951년 스페인 발렌시아 출생의 산티아고 칼라뜨 라바는 기술자, 예술가, 도시 계획가이다. 1968 69년 에 발렌시아 예술학교에서 미술을 공부하였으며, 1969 74년에 발렌시아 최고건축기술학교에서 건축공부 를 시작하였다. 1975 79년에 스위스 연방 공과대학 (ETH: Federal Institute of Technology)에서 도시공 학을 공부하며, 발렌시아에서 수학한 건축의 기하학 적 질서의 이해와 공학에 대한 견문을 넓히고자 했 으며, 1981년 공간 골격의 굴곡성에 관한 주제의 박 사 학위논문을 발표했다. 그는 약 14 년간 예술 - 건 축·토목 · 도시계획 · 기계기술을 배웠으며, 이러한 풍부하고 광범위한 교육수준은 그를 보다 체계적이 며, 과학적인 기술력으로 창조적인 디자인이 가능한 디자이너로 만들었다. 1981년 취리히에서 서른의 나이로 건축 - 토목공학 사무실을 차렸는데, 1983년 에 첫 공사 수주를 따낼 수 있었다. 조각적 분위기의 빌딩과 기차역, 사람들이 즐겨 이용할 수 있도록 공 간과 진입로를 갖추어 설계된 교량은 아치와 케이 블의 집합체라고 할 수 있다. 1980년대 중반부터 스 위스의 화랑과 미술관에서는 칼라뜨라바의 작품이 전시되기 시작했고, 80 년대 말에 이르러서는 미국 까지 전시가 기획되었다. 프랑스 건축 아카데미, 영 국구조공학협회에서 금상을 수상하며, 우수성을 인 정받았을 뿐만 아니라, 미술, 건축, 공학 관련 기관 에서 잇달아 수상하는 등 다양한 분야에서의 수상 
경력들은 그를 단순한 엔지니어로 치부해 버릴 수 없는 건축가임을 보여주고 있다.

'기하학적 형태의 언어는 건축에서 구조를 말하 는 중요한 수단이다.'라고 말하는 그의 수학적 기반 은 콘크리트의 잠재력, 그리고 자연물 형태에 대한 그의 열정과 결합되어 건축의 모습으로 나타났다. '자 연은 어머니이면서 스승이다(nature mater et magistra)' 라는 모토가 그의 모든 작업의 길잡이었다고 또한 그는 말한다(Rattenbury, \& Long, 2004/2006).

칼라뜨라바는 자연이나 생물에서 얻은 모티브의 형태적 의미를 건축적 형태의 의미로 변형하여 작 품을 제작하였다. 수많은 스케치로 정형화시킨 뒤 예술적 감각을 통해 상징적인 조형으로 표현한 그 의 작품은 합리적이며 기능적이고, 간단하면서 명확 하다. 〈Fig. 2〉는 칼라뜨라바의 형태구성 방법 중 생 물학적 형태로부터 ‘유추적 상상’을 통해 제작한 작 품으로, 구 모양의 메탈 구조는 마치 사람의 눈 위에 눈꺼풀이 덮이는 것처럼 움직이며, 움직이는 구조는 마치 진화를 거치는 것처럼 성장 및 형태의 변형을 보여주고 있다. 이렇게 인체의 형태, 원리를 해석하 여 적용함으로써 은유적 상징과 동적인 힘의 흐름 을 부여한 이 작품은 기술에 의한 가변적인 특성으 로 실질적 효용성과 구조적 경제성을 가져오는 특 징을 보여주고 있다. 〈Fig. 3〉은 연속된 구조부재의 배치로 인해 건축물에 속도감이 부여되고, 역동성이 표현되고 있음을 알 수 있는 작품이다. 이와 같이 칼 라뜨라바는 구조부재를 최대한 노출시키고, 반복적 으로 동일 부재를 배열함으로써 물리적인 흐름에 의한 운동감을 보여주고 있다.
또한 칼라뜨라바는 절제된 곡선미를 사용함으로 써 최소의 표현으로 외관을 나타내기도 하였는데, 1997년 제작한 교량(Fig. 4)은 갑판이 곡선에 마주 보게 퍼지는 경사를 만들어 설치된 하나의 아치의 특징을 이용하여 건축한 작품으로 충만한 한계상태, 결정적 순간의 표현으로 내포된 힘의 흐름을 표현 하고 있다. 중력적으로 불안적 요소를 디자인 요소 로 활용함으로써 균형과 불균형사이의 아슬아슬한 긴장감을 잘 보여주는 작품이다. 이와 같이 칼라뜨 라바는 구조적 형식의 건축을 만들기 위해 기능과 함께 형태에 심미적 언어를 표현하여 아름다운 형 식을 창조하는 성과를 나타내고 있다.

\section{The structural aesthetics expression trend} of Santiago Calatrava works

'구조(Structure)'란 네이버 사전에 의하면 “부분 이나 요소가 어떤 전체를 짜 이룸. 또는 그렇게 이루 어진 얼개(“Structure", n.d.a)"를 의미한다. 이는 사 물의 생김새나 모양을 의미하는 '형태'나 사물이 외 부로 나타나 보이는 모양을 뜻하는 '형식'과는 차이 가 있으며, 혼재되어 사용될 수 없다(Kim, S. I., 2012). 구조는 위키 백과사전에 의하면 때로는 형태가 없으 면서도 근본적인 어떤 것으로 둘러싸인 존재의 관계 및 개념 인식, 관찰, 자연, 양식의 안정성 등을 나타 내는 말이며, 물체가 짜여진 형태를 의미하기도 한 다(“Structure”, n.d.b). 건축에서 구조는 중요한 건축 의 기능 중 하나로 인간의 공간창조와 밀접하게 관 련되며, 공간은 부피감과 미관성이 부가될 때 더 충 실한 공간으로 규정된다. 이와 같이 건축의 공간구

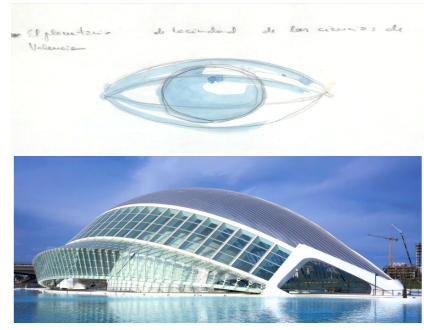

〈Fig. 2〉 Ciudad de las Artes y de las Ciencias Spain. (2004).

From. Santiago Calatrava (n.d.d). http://www.calatrava.com

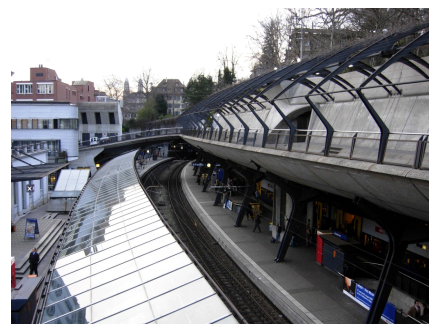

〈Fig. 3〉 Stadelhofen Station Switzerland. (1990).

From. Santiago Calatrava (n.d.e). http://www.calatrava. com

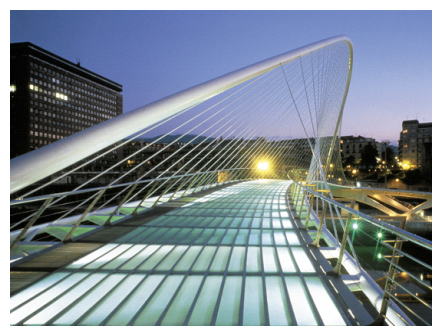

〈Fig. 4〉 Campo Volantin Foot Bridge Spain. (1997).

From. Borson (2010). http://www.lifeofanarchitect. com 
성에 있어서 구조란 필수불가결한 수단인 것이다. 구조미란 이러한 건축공간 구성 시 중력이라는 수직 하중에 대항할 적합한 재료를 사용하여 비례 와 대칭, 균형 등 각 요소들이 서로 조화롭게 구성되 어 미적 감동을 불러 일으켜 물리적 만족뿐만 아니 라, 심리적, 정신적 만족을 주는 것을 의미한다.

구조미를 보여주는 구성요소는 크게 선형요소, 평면요소, 입체요소로 분류할 수 있다. 건축에서 구 조적, 입체적 형태를 다양하게 표현하기 위해서는 형(Shape)을 이루는 선(Line)이 중요한 역할을 하는 데, 산티아고 칼라뜨라바의 건축의 조형적 특징 중 에 하나는 반복과 배치로 이루어진 다양한 '선'의 과학적 구조체계이다. 그는 구조체계의 형태적 다양 함을 극대화시키기 위해 직선과 곡선 등의 구조부 재를 연속적으로 배치하여 공간을 형성하고, 운동감 을 표현하였다.

특히, 그의 건축물 중에서 교량은 선의 활용을 가 장 분명하게 보여주고 있다. 칼라뜨라바가 설계한 교량인 알라미요 다리(Alamillo Birdge)는 1987년부 터 1992년에 걸쳐 스페인 세비야에 건설되었으며, 68도로 기울어진 이 다리는 직선의 구조부재를 반 복적으로 노출하여 자연스러운 역동성을 외부로 표 출하였다(Fig. 5). 또한 1987년 바르셀로나에서 준공 이 된 바끄 데 로다 다리(Bac De Roda-FelipeII Bridg) 는 직선과 곡선의 조화로움이 돋보이는 교량으로 바깥쪽에서 강철로 제작된 아치 두 개가 안쪽의 수 직으로 서 있는 두 개의 아치에 비스듬히 기댄 구조 로, 비스듬히 기댄 아치는 케이블로 상판과 연결하 여 마치 보행자를 에워싸는 듯한 느낌을 주고 있다.
이 교량에서는 공원을 조망할 수 있는 광장까지 마 련되어 있어 효용성에 있어서 사용자의 만족감을 높이고 있다(Fig. 6).

이처럼 주로 교량에서 사용되는 선의 특징 중 하 나는 방향성을 가졌다는 것인데, 수평선이 사용된 다 리의 도로, 인도부분에서는 고요함과 정지감으로 인 해 정적인 분위기를 표출한다. 활동성이 내포된 수직 선과 교량을 지탱하는 보조케이블 등의 사선은 움 직임과 동세를 보여주며, 동적인 분위기를 표출한다.

산티아고 칼라뜨라바의 건축의 조형적 특징 중에 형태는 시각적으로 가장 큰 부분을 차지한다. 앞에 서도 언급했던 바와 같이, 그는 유기적인 자연이나 인간의 신체에서 모티브를 얻어 함축적이고 상징적 인 건축물을 제작한다. 예를 들어, 비행하는 새의 날 개를 상징화한〈Fig. 7〉은 2001년 미국에 제작되었 으며, 다양한 수직선, 수평선, 사선의 유기적 결합으 로 상징적 구조체계에 운동성을 부여하고, 조형성을 더하였다. 일반적인 건축물의 경우, 매의 중첩과 적 층이나 분절에 의해 리듬감이 생성되지만, 칼라뜨라 바의 건축에서는 형태 관계 속에서 리듬이 생성된 다. 2003년부터 2011년에 걸쳐 제작된〈Fig. 8〉은 동 일한 형태가 규칙적으로 반복되면서 건축물의 꼭대 기까지 $90^{\circ}$ 각도로 뒤틀린 경이로운 초고층 빌딩이 다. 이 빌딩은 인간의 척추와 유사한 나선형 구조의 움직임이 돋보이며 회전하는 것처럼 생동감을 느끼 게 해주는 형태를 띠고 있다. 라이트 레일 트레인 브 릿지(Light Rail Train Bridge)는 균형과 불균형의 아 슬아슬한 한계상태에 있는 비대칭적 건축물이다 (Fig. 9). 중력을 거역하여 곧 넘어질 것 같은 불안한

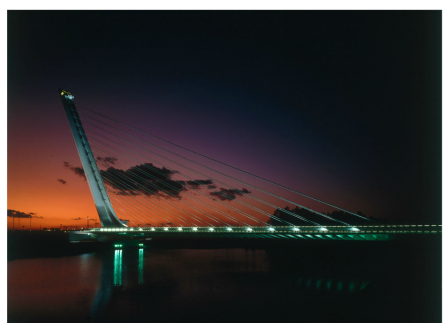

〈Fig. 5〉 Alamillo bridge Spain. (1992). 〈Fig. 6〉 Bac De Roda- FelipeII Bridg From. Santiago Calatrava (nd.a). http://www.calatrava.com

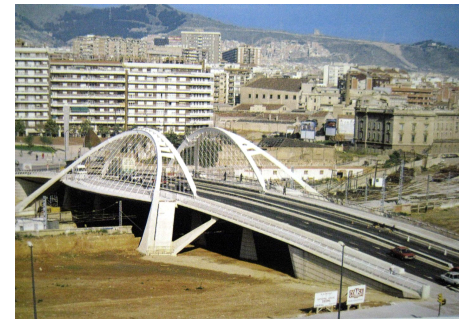

Spain. (1987). From. Santiago Calatrava (n.d.b). http://www.calatrava.com

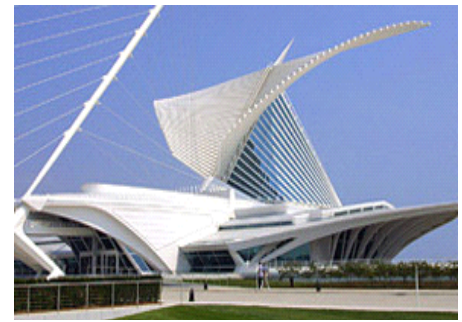

〈Fig. 7〉 Milwaukee Art Museum USA. (2001). From.

Milwaukee Art Museum (n.d.). http://mam.org/info/details/quadracci.php 

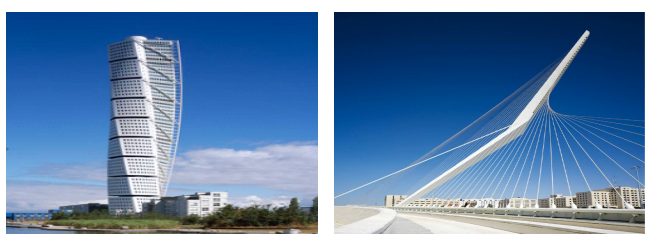

〈Fig. 8〉 Turning Torso sweden. (2005). From.

〈Fig. 9〉 Light Rail Train (LRT) Bridge Israel. (2008).

Santiago Calatrava (n.d.f). From. Santiago Calatrava www.calatrava.com (n.d.c). www.calatrava.com

심리상태를 유발하면서도 한편으로 이를 지탱하는 보조 케이블로 인해 안정감이 드는 형태를 보여준 다 할 수 있다.

칼라뜨라바는 건축물의 재료로 스스로 마감된 콘 크리트와 같은 자연석을 사용하였으며, 건축물의 무 게감 없이 움직일 수 있었던 이유는 조인트에 있다. 이러한 표현은 건물의 외관으로 표현되는데, 건축의 통합적 의미 회복, 구조체계 영역의 확장, 포괄적 고 려에 의한 디테일은 현대건축의 단일볼륨과 통합적 연결, 미니멀한 경향과 무관하지 않은 듯 보인다. 이 때 디테일은 건축의 고유 어휘의 회복에 중요 프로 세스로 역할을 한다. 구조부재들 간의 합리적인 응 력조절을 위하여 사용된 디테일은 또 다른 의미에 서의 새로운 건축미 창출에 일조한다(Kam, 2009). 디테일을 자세히 분석하면 칼라뜨라바가 실재구조 를 단지 도와주는 부분의 디테일은 철저하게 숨기 고, 구조미를 강조하는 디테일은 철저하게 드러내는 두 방식을 사용함을 알 수 있다.

이상과 같이 칼라뜨라바 디자인의 구조미 표현은 생물체의 구조에서 기능적 형태를 유추하여 표현하 는 생물학적 구조미, 구조체계의 힘의 흐름을 강조 하는 물리학적 구조미, 중력적으로 불안적 요소를 디자인 요소로 활용하는 탈중심적 구조미인 3 개의 주요내용으로 분류하였고, 이는 Kam(2009)의 연구 에서 제시된 생물학적 구조미, 물리학적 구조미, 반 중력적 구조미를 지지하는 결과로 보인다. 또한 구 조미를 표현하는 방식은 건축의 구성요소인 선형요 소, 평면요소, 입체요소로 나누어 분석할 때, 반복과 배치에 의한 운동감, 중첩과 분절에 의한 리듬감, 수 직 · 수평 - 사선에 의한 움직임과 동세, 방향성과 연 속성, 그리고 비대칭과 불균형에 의한 균형성 등의
디자인원리를 이용한 구축방식으로 표현한 것으로 나타나고 있다.

\section{Methods}

\section{The structural design definition}

구조적 디자인이란 평면상태의 옷감을 입체적인 인체에 맞도록 입체화시키는 과정에서 나타나는 구 조상의 디자인을 말한다. 의복을 구성하는 디테일과 그의 조합, 동시에 전체 실루엣을 의미하며, 의복의 구조적 변형을 통하여 생겨난 여러 가지의 양식으 로 패션에 나타난 형태의 변화, 즉 의복 실루엣 및 디테일 등을 하나의 스타일로써 통합하고 규명한 형식적인 모델이라고 할 수 있다(Choi, 2013). 따라 서 본 연구에서는 기존의 의복양식과 비교할 때 인 체의 형태나 의복의 실루엣, 표현방식, 디테일, 트리 밍 등 의복의 형태에 구조적 변형이 일어난 것을 구 조적 디자인이라 정의한다. 신체와 의복의 구조가 서로 조화를 이루는 가운데 현대적 감각으로 신체 의 부분을 과장하거나 왜곡하여 특정 부위를 은유 적으로 나타내거나, 해체된 형식의 혁신적인 스타일 의 디자인으로 현대 패션에서 두드러지게 나타나는 시도라고 할 수 있다. 패션에서의 구조적 디자인은 의복과 인체가 서로 돋보일 수 있는 조화로운 결합 이 요구되고 있다.

\section{The study object and scope}

실증적 연구의 범위는 2012년 F/W부터 2015년 $\mathrm{S} / \mathrm{S}$ 의 최근 3년간 프레타포르테(Pret-A-Porter: RTW) 여성복 컬렉션으로 선정하였다. Choi(2011)는 메종 마틴 마르지엘라, 알렉산더 맥퀸, 랄프 로렌, 존 갈 리아노, 장 폴 고띠에, 마크 제이콥스, 비비안 웨스 트우드, 칼 라거펠트, 돌체 앤 가바나, 레이 가와쿠 보, 후세인 샬라얀, 미우치아 프라다, 질 샌더를 구 조적이고 건축적인 디자이너로 언급하였고, Kim, J. M.(2012)은 그의 논문에서 릭 오웬스를 중점으로 연구하며 릭오웬스가 건축을 디자인요소로 접목하 는 디자이너로 표현하였다. Yoon(2014)의 연구에서 는 2003년 S/S부터 2014년 F/W까지 12년간 패션 디 자인에 표현된 건축적 모듈러 시스템의 사례 표집 결과, 파코 라반(Paco Rabanne), 이세이 미야케(Issey 
Miyake), 산드라 백룬드(Sandra Backlund), 프랭키 모렐로(Frankie Morello), 꼼 데 가르송(Comme des Garcons), 마틴 마르지엘라(Martin Margiela), 돌체 앤 가바나(Dolce \& Gabana)빅터 앤 롤프(Victor \& rolf) 순으로 나타나는 등 구조적 디자이너의 대한 다양한 분석이 있다.

본 연구에서 대상이 된 컬렉션 디자이너는 선행 연구인 Kim, S. I.(2012)의 연구에서 2009년 S/S부터 2012년 S/S까지 활동한 컬렉션 디자이너 349명을 대상으로 응답비율이 $50 \%$ 이상 되는 디자이너로 비 교 추출된 대표 디자이너 12 명 중 구조적 디자인의 표현특성인 '기하학적인 선과 면의 분할', ‘디테일 의 입체적인 부각', ‘그로테스크한 분해와 조립', ‘물 리적 조작에 의한 소재개발'의 출현빈도가 높은 대 표적인 디자이너 7명을 선별한 것으로 본 연구의 적 용에 부합되는 연구 자료라 할 수 있겠다. 선정된 디 자이너는 알렉산더 맥퀸(Alexander McQueen), 빅터 앤 롤프(Victor \& Rolf), 릭 오웬스(Rick Owens), 요 지 아마모토(Yohji Yamamoto), 레이 가와쿠보(Rei Kawakubo: Comme des Garcons), 메종 마틴 마르지
엘라(Maison Martin Margiela), 가레스 푸(Gareth Pugh) 이다.

본 연구에서는 선행연구 자료와의 연속성과 최신 자료로의 갱신을 위하여 자료의 수집을 최근 3 년간 컬렉션으로 제한하였으며, 자료 수집은 2014년 12 월부터 2015년 2월까지 90일 기간 동안 패션전문 사이트 www.style.com에서 추출하였다. 연구자료 분석은 F.G.R.(Focus Group Research)를 실시하였으 며, F.G.R.의 구성은 패션디자인을 전공하는 석사학 위 이상인 자로 3 인을 선정하여 연구에 대한 전문적 이고, 객관적인 판단으로 결과에 대한 신뢰도를 높 였다. 추출 및 분석에 사용된 사진자료는 추출한 총 1,508 장 중 640 장의 사진을 분석하였다.

\section{Results and Discussion}

\section{The structural aesthetics expression in the} structural fashion design

앞서 고찰한 칼라뜨라바 건축의 구조미 표현은 생물학적 구조미, 물리학적 구조미, 탈중심적 구조

$\langle$ Table 1〉 The structural design appearance frequency of each designer and season

\begin{tabular}{|c|c|c|c|c|c|c|c|c|c|}
\hline \multirow{2}{*}{\multicolumn{2}{|c|}{ Designer }} & \multirow{3}{*}{$\begin{array}{l}2012 \\
\text { F/W } \\
18 / 36\end{array}$} & \multirow{3}{*}{$\begin{array}{c}2013 \\
\mathrm{~S} / \mathrm{S} \\
19 / 31\end{array}$} & \multirow{3}{*}{$\begin{array}{c}2013 \\
\text { F/W } \\
6 / 6\end{array}$} & \multirow{3}{*}{$\begin{array}{c}2014 \\
\mathrm{~S} / \mathrm{S} \\
10 / 32\end{array}$} & \multirow{3}{*}{$\begin{array}{l}2014 \\
\text { F/W } \\
13 / 34\end{array}$} & \multirow{2}{*}{$\begin{array}{c}2015 \\
\mathrm{~S} / \mathrm{S}\end{array}$} & Frequency & Ratio(\%) \\
\hline & & & & & & & & \multicolumn{2}{|c|}{ Total } \\
\hline \multirow{2}{*}{ Alexander Mcqueen } & Frequency & & & & & & $9 / 35$ & \multirow{2}{*}{$75 / 174$} & \multirow{2}{*}{11.7} \\
\hline & Ratio(\%) & 50 & 61.3 & 100 & 31.3 & 38.2 & 25.7 & & \\
\hline \multirow{2}{*}{$\begin{array}{c}\text { Rei Kawakub } \\
\text { (Comme des Garçons) }\end{array}$} & Frequency & $18 / 39$ & $36 / 36$ & $21 / 34$ & $20 / 23$ & $21 / 22$ & $19 / 22$ & \multirow{2}{*}{$135 / 176$} & \multirow{2}{*}{21.1} \\
\hline & Ratio(\%) & 46.2 & 100 & 61.8 & 87 & 95.5 & 86.4 & & \\
\hline \multirow{2}{*}{ Gareth Pugh } & Frequency & $32 / 39$ & $29 / 34$ & $19 / 51$ & $19 / 41$ & $29 / 42$ & $22 / 40$ & \multirow{2}{*}{$150 / 247$} & \multirow{2}{*}{23.4} \\
\hline & Ratio(\%) & 82.0 & 85.3 & 37.3 & 46.3 & 69.0 & 55.0 & & \\
\hline \multirow{2}{*}{ Martin Margiela } & Frequency & $22 / 42$ & $29 / 36$ & $2 / 30$ & $16 / 31$ & $9 / 32$ & $13 / 36$ & \multirow{2}{*}{$91 / 207$} & \multirow{2}{*}{14.2} \\
\hline & Ratio(\%) & 52.4 & 80.6 & 6.7 & 51.6 & 28.2 & 36.1 & & \\
\hline \multirow{2}{*}{ Rick Owens } & Frequency & $5 / 42$ & $11 / 34$ & $11 / 42$ & $8 / 23$ & $12 / 40$ & $17 / 45$ & \multirow{2}{*}{$64 / 226$} & \multirow{2}{*}{10.0} \\
\hline & Ratio(\%) & 12.0 & 32.4 & 26.2 & 34.8 & 30.0 & 37.8 & & \\
\hline \multirow{2}{*}{ Viktor \& Rolf } & Frequency & $17 / 42$ & $14 / 24$ & $11 / 35$ & $7 / 34$ & $19 / 44$ & $6 / 34$ & \multirow{2}{*}{$74 / 213$} & \multirow{2}{*}{11.6} \\
\hline & Ratio(\%) & 40.5 & 58.3 & 31.4 & 20.6 & 43.1 & 17.6 & & \\
\hline \multirow{2}{*}{ Yohji Yamamoto } & Frequency & $7 / 40$ & $5 / 46$ & $5 / 39$ & $9 / 48$ & $17 / 42$ & $8 / 50$ & \multirow{2}{*}{$51 / 265$} & \multirow{2}{*}{8.0} \\
\hline & Ratio(\%) & 17.5 & 10.9 & 12.8 & 18.8 & 40.5 & 16.0 & & \\
\hline \multirow{2}{*}{ Total } & Frequency & $119 / 280$ & $143 / 241$ & $75 / 237$ & $89 / 232$ & $120 / 256$ & $94 / 262$ & \multirow{2}{*}{$640 / 1,508$} & \multirow{2}{*}{100} \\
\hline & Ratio(\%) & 18.6 & 22.3 & 11.7 & 14.0 & 18.8 & 14.7 & & \\
\hline
\end{tabular}


미로 나타나고 있다. 구조적 패션디자인의 표현방식 을 분석하기 위하여 이론적 배경을 중심으로 선행 연구를 분석하면 다음과 같다.

먼저 건축과 패션분야에서 $\operatorname{Shin}(2008)$ 은 안토니 오 가우디의 건축작품의 형태미를 구조적 형태미와 자연적 장식미, 시각적 색채미로 분류하였다. $\mathrm{Kim}$ (2009)은 건축의 조형성이 반영된 현대 패션의 특성 을 다변형성, 양면성, 절제성으로 연구하였고, Cho (2011)는 자하 하디드 건축의 조형적 특성을 비정 형성, 다공성과 유동성, 중첩성으로 나누어 연구하 였다. 피터아이젠만 건축 작품의 조형적 특성을 연 구한 $\operatorname{Sohn}(2013)$ 은 비정형성, 반복성, 중첩성과 탈 중력성으로 특성을 연구하였고, 오스카 니마이어의 건축의 조형적 특성을 연구한 $\operatorname{Im}(2015)$ 은 1) 자유 조형 형태, 곡면 형태, 왜곡, 연속성의 형태와 2) 역 동적인 실루엣, 유기적인 곡선, 반복에 의한 방향성 과 질서, 3) 비대칭, 비균형, 비정형으로 분류하였 다. 패션디자인 분야에서 Kim, B. M.(2012)는 알렉 산더 맥퀸의 패션에 표현된 건축적 탈정형 공간의 표현방식을 비선형성, 연속성과 역동성, 탈구축성 으로 분류하였다. Kim, S. I.(2012)은 현대 패션에 나타난 구조적 디자인의 특성을 기하학적인 선과
면의 분할, 물리적 조작에 의한 소재의 개발, 그로 테스크한 분해와 조립과 디테일의 입체적인 부각 으로 구분하여 설명하였고, 산드라 백룬드의 컬렉 션에 나타난 구조적 디자인의 특성을 연구한 Choi (2013)는 과장성, 기하학적 구조와 텍스트의 입체 적 변형, 해체성을 구조적 디자인의 특성으로 연 구하였다. 건축의 구조미와 패션에 관한 해외 연 구가 부족한 실정으로 분석된 선행연구 논문 모 두가 국내 연구자 논문인 점은 연구의 제한점으 로 나타났다.

이상의 선행연구자들이 제시한 구조적 디자인의 특성을 구조미의 표현방식별로 구분하면 〈Table 2〉 와 같다.

칼라뜨라바 건축의 구조미를 중심으로 분석한 구조적 패션디자인에 나타난 구조미는 1) 상징적인 유추와 해석을 통한 미적표현인 상징적 조형미, 2) 시각적인 강조와 움직임에 의한 표현인 물리적 역 동미, 3) 균형과 불균형 사이의 경계에서 균형 쪽으 로 전이되는 표현으로의 비대칭적 균형미로 분류 하였다.

최근 3 년간 패션디자인의 구조미에 따른 디자이 너별 디자인 출현빈도는〈Table 3 〉과 같다.

$\langle$ Table 2〉 The structural fashion design feature in architecture

\begin{tabular}{|c|c|c|c|}
\hline $\begin{array}{l}\text { Researcher/ } \\
\text { architecture }\end{array}$ & Biological structural aesthetics & Physical structural aesthetics & $\begin{array}{c}\text { Decentralized structural } \\
\text { aesthetics }\end{array}$ \\
\hline Shin, H. J.(2008) & $\begin{array}{l}\text { Structural physical beauty, } \\
\text { natural decorating beauty }\end{array}$ & Visual beauty of color & \\
\hline Kim, Y. K.(2009) & Diverse strain & Double sidedness & Self controllability \\
\hline Cho, Y. K.(2011) & Atypia & Porosity, liquidity & Duality \\
\hline Kim, B. M.(2012) & Nonlinearity & Continuity, dynamics & Deconstruction \\
\hline Kim, S. I.(2012) & $\begin{array}{l}\text { Geometrical division of line and } \\
\text { face }\end{array}$ & $\begin{array}{l}\text { Material development by } \\
\text { physical operation }\end{array}$ & $\begin{array}{l}3 \text { dimensional embossing of } \\
\text { grotesque disassembly and } \\
\text { assembly detail }\end{array}$ \\
\hline Choi, K. H.(2013) & Expansion & $\begin{array}{l}3 \text { dimensional transformation } \\
\text { of geometrical structure texts }\end{array}$ & Dismantlism \\
\hline Im, S. M.(2015) & $\begin{array}{l}\text { Form of free shape/form of } \\
\text { curved surface, distortion, } \\
\text { continuity form }\end{array}$ & $\begin{array}{c}\text { Dynamic silhouette, organic } \\
\text { curved line/direction and order } \\
\text { by repetition }\end{array}$ & Asymmetry, imbalance, atypia \\
\hline \multicolumn{4}{|c|}{$\square$} \\
\hline Fashion & Symbolical formative aesthetic & Dynamic beauty of physic & $\begin{array}{l}\text { Asymmetric beauty of } \\
\text { symmetry }\end{array}$ \\
\hline
\end{tabular}


〈Table 3〉 The structural design appearance frequency for each designer

\begin{tabular}{c|c|c|c|c|c|c|c|c}
\hline \multirow{2}{*}{ Designer } & $\begin{array}{c}\text { Symbolical formative } \\
\text { aesthetic }\end{array}$ & $\begin{array}{c}\text { Dynamic beauty of } \\
\text { physic }\end{array}$ & $\begin{array}{c}\text { Asymmetric beauty of } \\
\text { symmetry }\end{array}$ & \multicolumn{3}{c}{ Total } \\
\cline { 2 - 10 } & Frequency & Ratio(\%) & Frequency & Ratio(\%) & Frequency & Ratio(\%) & Frequency & Ratio(\%) \\
\hline Alexander Mcqueen & 34 & 24.8 & 24 & 5.6 & 17 & 13.7 & 75 & 10.9 \\
\hline $\begin{array}{c}\text { Rei Kawakub } \\
\text { (Comme des Garçons) }\end{array}$ & 20 & 14.6 & 126 & 29.4 & 5 & 4.0 & 151 & 21.9 \\
\hline Gareth Pugh & 49 & 35.8 & 85 & 19.9 & 16 & 12.9 & 150 & 21.8 \\
\hline Maison Martin Margiela & 11 & 8.0 & 68 & 15.9 & 19 & 15.3 & 98 & 14.2 \\
\hline Rick Owens & 4 & 2.9 & 48 & 11.2 & 13 & 10.5 & 65 & 9.4 \\
\hline Viktor \& Rolf & 8 & 5.8 & 41 & 9.6 & 25 & 20.2 & 74 & 10.7 \\
\hline Yohji Yamamoto & 11 & 8.0 & 36 & 8.4 & 29 & 23.4 & 76 & 11.0 \\
\hline Total & 137 & 100 & 428 & 100 & 124 & 100 & 689 & 100 \\
\hline
\end{tabular}

※ Allow duplicate data

\section{1) The symbolical formative aesthetic}

산티아고 칼라뜨라바는 자연에서 보여지는 형태 나 모티브를 건축의 형태로 의미를 반영하여 변형 하였다. 인체의 팔, 다리, 눈동자 등 인체의 부분을 주제로 하거나, 새나 꽃, 나무와 같은 생물체나 자연 물의 형태를 유추 구상의 주제로 건축물의 형태로 변형하는 상징적 유추 해석법을 적용하여 조형미를 표현하였다.

예술에서의 상징이란 작품 자체이며, 시각적 형식 을 말하는데, 구조적 패션디자인에서는 이러한 시각 적 형식을 자연과 다양한 모티브의 형태적 의미로
표현하였다. 가레스 푸는 새의 형상을 떠올리는 과 장된 실루엣으로 깃털소재와 헤어장식을 사용해 생 물체의 상징성을 더욱 가중시켰다(Fig. 10). 알렉산 더 맥퀸은 특히 자연물을 이용한 상징적 이미지의 디자인을 많이 하였는데, 그 중〈Fig. 11〉은 자연물 중 꽃을 형상화한 디자인으로, 여러 겹의 반복적인 러플디테일로 풍성함을 살려주어 마치 한 송이의 꽃이 피어나는 느낌을 주었고, 이는 인체를 무시한 탈구조적인 디자인으로 예술적 심미성, 자연성을 강 조하고 있다. 〈Fig. 12〉 또한 벌을 모티브로 한 디자 인으로, 원통형 벌집 그물 헤드피스에서부터 벌집

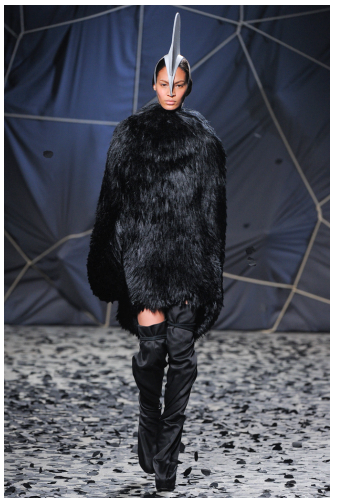

〈Fig. 10〉 Gareth Pugh 2012 F/W. From. Gareth Pugh (n.d.a). http://www.style.com

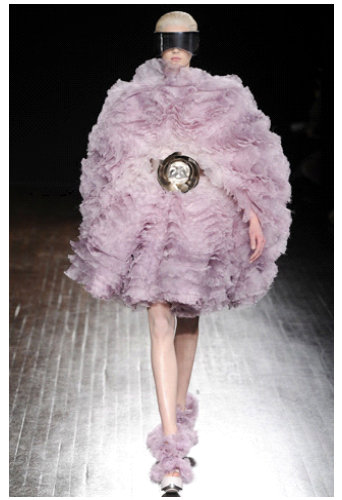

〈Fig. 11〉 Alexander Mcqueen 2012 F/W. From. Alexander Mcqueen (n.d.a). http://www.style.com

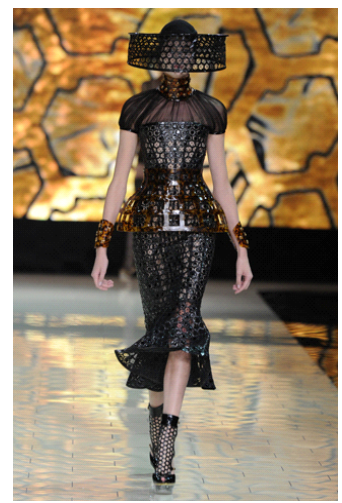

〈Fig. 12〉 Alexander Mcqueen 2013 S/S. From. Alexander Mcqueen (n.d.c). http://www.style.com 
형태의 비즈 장식 벨트, 초커와 뱅글, 그물 부츠, 페 플럼과 코르셋까지 패션디자인에 사용하였다. 의복 의 안쪽에 놓여야 할 코르셋을 오히려 의복의 표면 으로 위치 전환하여 드러냄으로써 기이한 조화를 창조하였고, 페플럼과 코르셋으로 모델들의 허리는 모래시계처럼 더욱 잘록해져 조형미가 돋보이는 작 품이다.

이와 같이 구조적 패션디자인에 나타난 상징적 조형미는 유기체의 유추, 해석을 통한 형태구성 접 근으로 구조미를 표현하였으며, 디자이너는 가레스 푸(35.8\%), 알렉산더 맥퀸(24.8\%), 레이 가와쿠보 $(14.6 \%)$ 의 작품에 많이 나타났으며, 그 외에도 메종 마틴 마르지엘라, 요지야마모토, 빅터 앤 롤프, 릭 오웬스의 작품 순으로 표현된 것으로 나타났다 (Table 2).

\section{2) The dynamic beauty of physic}

산티아고 칼라뜨라바 작품의 구조체계는 마치 살 아있는 것처럼 움직이는 듯한 힘의 흐름을 강조하 는 구조미를 보여주는데, 구조 자체만으로도 많은 건축적 효과를 만들어내고 있다.

패션에서의 물리적 역동미란 동일한 패턴을 연 속적으로 배열함으로써 운동성을 시각적으로 강조 하는 것에서 많이 나타난다. 즉, 선이나 형태에서 나타나는 리듬과 물리적 변형에 의한 소재 개발을 토대로 움직임을 표현하는 것이다. 이러한 물리적
역동미는 선과 면의 활용을 분명하게 보여준 빅터 앤 롤프의 작품에서 잘 나타나고 있다(Fig. 13). 그 는 입체적 절개에 의한 선형요소와 평면 분할을 활 용하여 직선과 곡선의 조화를 반복적으로 노출하 여 자연스러운 역동성을 외부로 표출하였다. 선의 중요한 특징 중에 하나인 방향성에 의해 움직임과 동세를 내포하고 있으며, 사선은 활동성을 내포하 고 있다. 가레스 푸는 에 나멜, 메탈릭 소재를 사용 함으로써 하이테크적인 활동적 이미지를 더욱 극 대화 시켰으며, 기계적 이미지의 소재에 물리적 변 형을 가하여 목을 감싸 올라가며, 힘의 흐름을 강 조하는 네크라인과 사선 방향으로 떨어지는 실루 엣으로 동세미와 세련된 움직임의 미학을 공학적 으로 표현함으로써 표면구조의 시각적 강조와 함 께 물리적 역동미를 보여주었다(Fig. 14). 또한 꼼 데 가르송은 〈Fig. 15〉에서 보여지듯이, 하나의 거 대한 구조물에 파이핑 처리된 사선 방향의 곡선은 물리적인 변형에 의한 역동적 힘의 흐름을 느끼게 해주며, 절개선을 부분적으로 이용하여 외형을 기 하학적 형태로 변화시켜 시각적으로 보여지는 구조 적 조형미을 부각시켰다. 이러한 물리적 역동미는 레이 가와쿠보(29.41\%), 가레스 푸(19.9\%), 메종 마 틴 마르지엘라(15.9\%)의 작품에 많이 나타났으며, 그 외에도 릭 오웬스, 빅터 앤 롤프, 요지 야마모토, 알렉산더 맥퀸의 작품 순으로 표현된 것으로 나타 났다(Table 2).

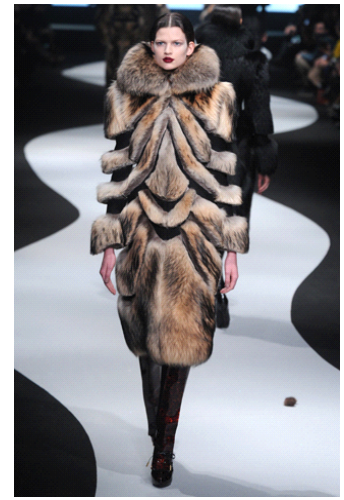

〈Fig. 13〉 Viktor \& Rolf 2012 F/W. From. Viktor \& Rolf (n.d.a). http://www.style.com

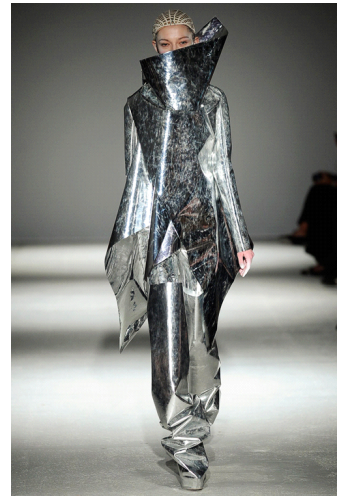

〈Fig. 14〉 Gareth Pugh 2014 F/W. From. Gareth Pugh (n.d.c). http://www.style.com

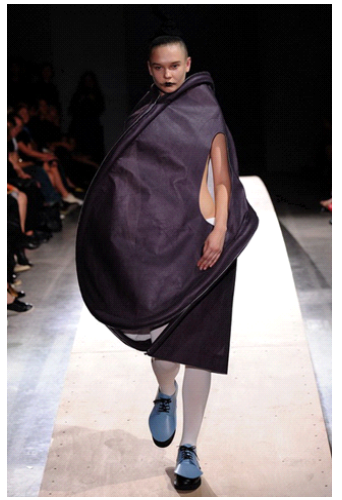

〈Fig. 15〉 Rei Kawakub (Comme des Garçons) 2014 S/S. From. Comme des Garçons (n.d.c). http://www.style.com 
3) The asymmetric beauty of symmetry

비대칭이란 중심의 상하 또는 좌우를 같지 않게 배치하는 것으로 칼라뜨라바는 구조 부재를 배치함 에 있어 대칭-비대칭 효과를 사용하였다. 특히 단면 의 2 차원 평면에서 힘의 평형이론으로 해석된 구조 부재를 연속적으로 배치하여 공간을 형성하고, 운동 감을 부여하였다. 그리고 힘의 대칭으로 균형을 확 보하는 동시에, 이러한 힘들을 엇갈려 배치함으로써 비대칭을 확보하여 구조물의 형상을 달리 취함으로 써 독특한 형태를 만들어냈다. 현대건축의 구조미는 독창성을 표현하는 특징으로 나타나고 있는데, 단순 히 표피의 외부에 뼈대를 드러내는 것이 아닌, 기존 에 답습하던 형태와 양식을 벗어나 새로운 형태를 보여주고 있다. 또한 반복적이고 기울어진 구조는 자연스럽게 동적인 운동감을 보여주고, 운동감은 다 시 건축물 전체에 일정하게 힘의 흐름을 표현해 내 고 있다.

현대 구조적 패션에서도 이러한 비대칭적 균형미 가 균형과 불균형 사이의 경계에서 균형 쪽으로 전 이되는 표현으로 나타나고 있다. 〈Fig. 16〉의 빅터 앤 롤프는 화이트 셔츠의 면을 기하학적이면서 불 규칙적으로 분할하였다. 분할된 면의 주름 길이를 각각 다르게 하여 불균형적인 비대칭적 형태를 보 여주고 있다. 비대칭적으로 부각된 셔츠의 햄라인이 블랙 팬츠의 햄라인과 겹쳐지면서 무게중심이 한쪽 으로 치우치지 않은 느낌을 주어, 정형화되지 않은
균형감을 느낄 수 있다. 〈Fig 17〉의 레이 가와쿠보 는 전통적 패턴 구성방법에서 일반적으로 사용되는 절개나 햄라인이 아닌, 부분을 반복적으로 절개하 고, 이를 봉제하는 물리적 변형을 주었다. 신체사이 즈보다 크게 만들어진 이 의상은 입체감으로 인해 부피와 양감이 느껴지며, 좌우 비대칭으로 불균형의 미를 새롭고 독창적으로 제시하고 있다. 〈Fig. 18〉 은 여러 기능을 수행하는 가변적 디자인을 이용한 비대칭 롱스커트이다. 가변적 디자인은 미래 환경 변화에 대응하려 하는 현대인의 요구와 유동적으로 개방적 열린 패션의 한 형태로 자리 잡으며, 21 세기 패션 트렌드로 부상하고 있다. 요지 야마모토는 스 커트 중간에 지퍼를 이용하여 비대칭적이면서도 균 형있는 모습을 연출하였고, 지퍼를 열고 닫음으로써 탈착이 가능한 가변적인 디자인을 보여주었다.

이와 같이 비대칭적 균형미는 의복에서 중심이 되는 앞 중심, 다트, 옆선 등의 수직적 균형과 소매 끝단, 치맛단 등의 수평 균형을 파괴하면서도 불균 형을 이룬 각 요소들이 서로 조화를 이뤄 새로운 균 형미를 창조하는 것으로 나타나고 있다.

이러한 비대칭적 균형미를 잘 보여주는 구조적 디자이너로는 요지야마모토(23.4\%), 빅터 앤 롤프 (20.2\%), 메종 마틴 마르지엘라 $(15.3 \%)$ 의 작품에 많 이 보여지고 있으며, 그 외에도 알렉산더 맥퀸, 가레 스 푸, 릭 오웬스, 레이 가와쿠보의 순으로 나타났다 (Table 2).

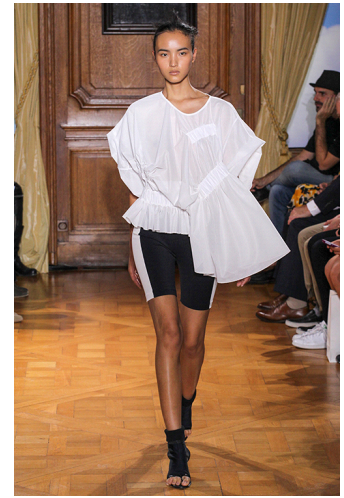

〈Fig. 16〉 Viktor \& Rolf 2015 S/S. From. Viktor \&Rolf (n.d.b). http://www.style.com

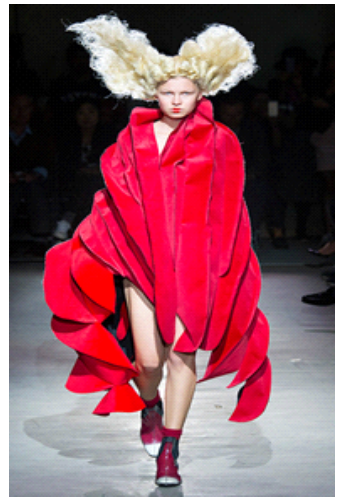

〈Fig. 17〉 Rei Kawakub (Comme des Garçons) 2015 S/S. From. Comme des Garçons (n.d.e). http://www.style.com

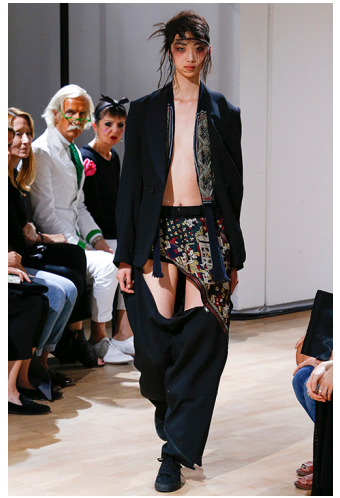

〈Fig. 18〉 Yohji Yamamoto 2015 S/S.

From. Yohji Yamamoto (n.d.). http://www.style.com 
2. The expression method in the structural fashion to maximize the structural aesthetics

선행연구와 칼라뜨라바 건축의 표현특성을 중심 으로 분석해볼 때, 현대패션에 나타난 구조미를 극 대화하는 표현방법은 1) 외관형태의 상징적, 구조적 과장, 2) 디테일 기법의 확장과 재료 물성의 다양화, 3) 구조와 외피표현의 입체적 변형으로 구분할 수 있다.

\section{1) Symbolical and structural exaggeration of} appearance

외관형태의 상징적, 구조적 과장은 유추적 상상 과 은유적 해석을 디자인에 가미시켜 실루엣에 반 영하거나, 의복의 전체 또는 구성 요소의 형태를 변 화시켜 무정형적인 실루엣으로 창조하는 왜곡의 방 법으로 나타났다. 왜곡은 인체를 고려하여 의복을 강조, 생략하는 '인체 재현적 왜곡'과 인체를 하나 의 조형물로 보고, 의복 형태 자체를 왜곡하는 '인체 비재현적 왜곡‘의 방식으로 나타났으며 $(\mathrm{Kim}, \mathrm{S}$. I., 2012), 또한 구조적 패션에서는 어떠한 사물의 기능 이나 형태를 추측할 수 있도록 상징적으로 표현하 는 유추, 형태를 해체하고, 예기치 못한 형태로 달라 지게 하는 변형, 어떠한 사물의 기능이나 형태를 본
뜨거나, 차용한 모방 등의 다양한 디자인 방식을 이 용하여 외관형태를 상징적, 구조적으로 과장하여 표 현하였다. 이러한 표현은 인체를 무시한 탈구조적 스케일의 실루엣으로 예술적 심미성을 나타내기도 했는데, 〈Fig. 19〉의 작품에서 알렉산더 맥퀸은 퍼 소재를 여러 겹으로 겹쳐 실루엣은 확대하고, 디테 일은 축소한 과장된 구조적 외관의 형태를 보여주 었다. 여러 겹으로 겹쳐진 구조는 반복과 점진 기법 에 의해 리듬을 형성하여 운동감을 나타내고, 이러 한 구조는 인체 위에 옷을 입은 것이 아닌 인체가 구조물 속에 들어가 있는 듯한 느낌을 주고 있다. 레 이 가와쿠보는 $2012 \mathrm{~F} / \mathrm{W}$ 컬렉션에서 외관형태를 상 징적, 구조적으로 과장시켜 신체의 구조를 무의미하 게 만드는 의상들을 선보였는데, 단순하게 종이 두 장을 자르고 접고 붙여 만든 듯한 펠트 의상은 마치 의상이 또 다른 의상의 배경인 듯한 착시를 불러일 으키며, 내부의 의상을 강조시키며, 구조적 표현을 극대화시켜 패션의 선입견과 상상력을 무력화시켰 다. 단추와 지퍼 하나 없이 연결된 코트(Fig. 20)는 거대한 볼륨의 파란색 펠트 드레스 위에 여성의 실 루엣에 따른 분홍색 반팔 펠트 드레스 모양을 덧대 어, 마치 의상에 또 다른 의상의 배경인 듯한 착시를 불러일으키며, 독창적인 컬러 블록 효과를 내고 있

〈Table 4〉 The expression method to maximize the structural aesthetics

\begin{tabular}{|c|c|c|c|c|}
\hline \multicolumn{2}{|c|}{$\begin{array}{c}\text { Structural aesthetics } \\
\text { of structural fashion } \\
\text { design }\end{array}$} & \multirow{2}{*}{$\begin{array}{c}\text { Symbolical formative aesthetic } \\
\begin{array}{c}\text { Symbolism, originality, } \\
\text { naturalness, esthetic }\end{array}\end{array}$} & \multirow{2}{*}{$\begin{array}{c}\text { Dynamic beauty of physic } \\
\text { Mobility, continuity, } \\
\text { repeatability, formality }\end{array}$} & \multirow{2}{*}{$\begin{array}{c}\text { Asymmetric beauty of } \\
\text { symmetry }\end{array}$} \\
\hline \multirow[b]{2}{*}{$\begin{array}{l}\text { Expression } \\
\text { of } \\
\text { structural } \\
\text { aesthetics }\end{array}$} & Features & & & \\
\hline & Expression & $\begin{array}{l}\text { - Symbolical inference and } \\
\text { analyzation } \\
\text { - Distortion, transformation } \\
\text { - Antistructural silhouette of } \\
\text { ignoring the human body } \\
\text { - Visual expression emphasis } \\
\text { - Artistic esthetics emphasis }\end{array}$ & $\begin{array}{l}\text { - Geometrical division of line } \\
\text { and face } \\
\text { - Material development by } \\
\text { physical transformation } \\
\text { - } 3 \text { dimensional embossing of } \\
\text { surface structure } \\
\text { - Mechanical beauty by high- } \\
\text { tech }\end{array}$ & $\begin{array}{l}\cdot \text { Asymmetric structure } \\
\cdot \text { Understated curves } \\
\text { - Changeable desorption } \\
\text { structure } \\
\text { - Mixed with other elements }\end{array}$ \\
\hline \multicolumn{2}{|c|}{ Expression method } & $\begin{array}{l}\text { Symbolism, structural } \\
\text { exaggeration }\end{array}$ & $\begin{array}{l}\text { Detail technique expansion, } \\
\text { diversificaltion of material }\end{array}$ & $\begin{array}{c}\text { Transformation of structure and } \\
\text { shell expression }\end{array}$ \\
\hline
\end{tabular}




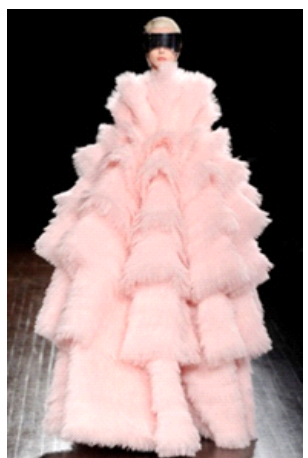

〈Fig. 19〉 Alexander

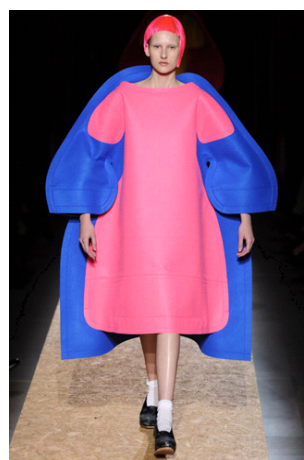

〈Fig. 20〉 Rei Kawakub (Comme des Garçons) 2012 F/W. From. Comme des Garçons (n.d.a). http://www.style.com Mcqueen 2012 F/W. From Alexander Mcqueen (n.d.b). http://www.style.com

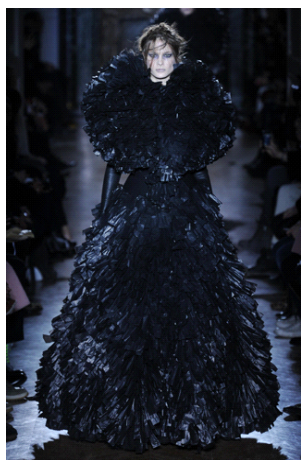

〈Fig. 21〉 Gareth Pugh 2013 F/W. From. Gareth Pugh (n.d.b). http://www.style.com

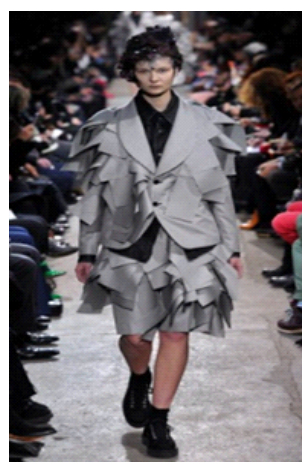

〈Fig. 22〉 Rei Kawakub (Comme des Garçons) 2013 F/W. From. Comme des Garçons (n.d.b). http://www. style.com
다. 인체를 무시한 파란색 펠트 드레스 위에 인체를 의식한 분홍색 반팔 드레스를 덧대는 것으로 인체 비재현적이면서도 인체 재현적인 왜곡을 보여줌으 로써 예술적 심미성이 강조되고 있다.

2) Detail technique expansion and material property diversification

디테일이란 '부분 - 세부’라는 뜻으로 복식에서 의복이 구성되어지는 과정에서 만들어지는 부분적 인 장식을 뜻하며, 칼라·네크라인·소매·커프 스-포켓 - 다트- 절개 등 다양한 부분을 포함한다 (Kim, S. I., 2012).

가레스 푸는 의복의 소재로 부적합하다고 여겨져 배제하고 소외시켰던 '쓰레기봉투’를 자르고, 감고, 반복적으로 중첩시켜 다양한 재료 물성을 소재로 도입시키고, 디테일 기법을 다양하게 구성함으로써 시선을 집중시키는 효과를 주었다(Fig. 21). 구조적 경제성, 기술을 통한 환경의 조절 등을 목표로 한 하 이테크 건축과 실질적 효용성과 지속가능한 패션으 로서의 경제성을 추구한다는 점에서 동향을 보여주 는 작품이라 할 수 있다.

또한 구조적 패션에서는 일반적으로 사용되는 소 재인 패브릭뿐만 아니라, 깃털, 플라스틱, 메탈릭 등 다양한 소재를 혼용하여 사용하였는데, 〈Fig. 22〉의 레이 가와쿠보 작품은 각각의 패널을 기하학적으로
재단된 원단을 붙여 독창적으로 표현하였다. 이러한 작품들은 동일한 직사각형 모양의 개체를 거듭하여 겹치고 포갬으로써 디테일 기법을 확장시켜 2차원 의 소재로 새로운 구조적 외관 형태를 나타내어 시 각적 표현을 강조하였다.

3) 3 dimensional transformation of structure and shell expression

2 차원적인 평면의 소재를 3 차원적인 인체에 입히 기 위해서는 물리적 가공을 거쳐야 하는데, 현대 구 조적 패션에서는 의복구조의 분해와 조립을 통한 구조와 외피표현의 입체적 변형으로 구조적 표현을 나타내었다.

릭 오웬스는 전통적 패턴 구성방법에서 일반적으 로 사용되는 절개나 햄라인이 아닌, 넥 라인이 있을 자리에 여러 크기로 만들어진 소매를 배치하였고, 이로 인해 구조가 입체적으로 과도하게 부각되고 있다. 이렇게 반복, 점진, 연속적이고 규칙적인 흐름 에 의한 운동감을 형성 하는 방법으로 표면구조를 입체적 부각시켜 외관을 확장하고 있음을 알 수 있 다(Fig. 23).

레이 가와쿠보의 〈Fig. 24〉는 구조부재가 의복의 표면으로 노출되어 의복을 지지해주는 버팀대로 사 용된 것이 아닌 하나의 모티브로 사용되고 있다. 의 복 외부에 직선으로 연결된 플라스틱 구조부재와 


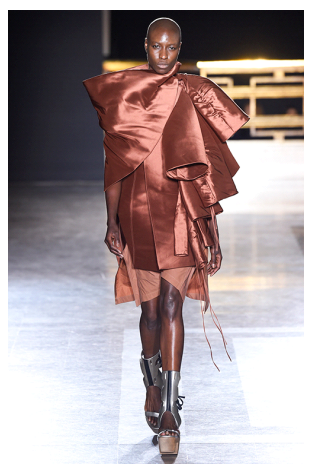

〈Fig. 23〉 Rick Owens 2015 S/S. From. Rick Owens (n.d.). http://www.style.com

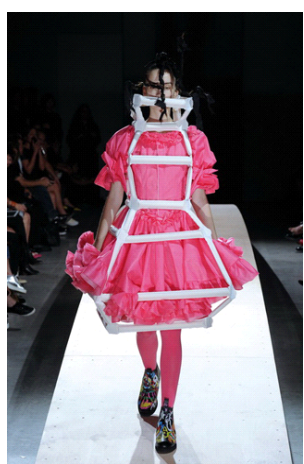

〈Fig. 24〉 Rei Kawakub (Comme des Garçons) 2014 S/S. From. Comme des Garçons(n.d.d). http://www.style.com
의복 내부에 러플이 잡힌 핑크 색상의 로맨틱한 원 피스는 서로 대립적으로 보이는 다른 요소들이 혼 성되면서 의복에서 충돌을 일으키는 동시에 시각적 인 공간감을 주고 있다. 이 외에도 현대 구조적 패션
에서는 의복구조의 분해와 조립, 탈착 가능한 가변 성 등의 구축방식을 사용하여 구조적 패션디자인의 구조미의 극대화를 보여주었다.

현대 구조적 패션디자인은 이러한 다양한 표현방 법을 통해 예술적 심미성을 확보함과 동시에, 기존 의 형태와 양식을 파괴하고, 새로운 독창적 형태로 구성함으로써 구조미의 효과를 표현한 것으로 나타 났다. 또한 구조적 패션에 있어서 구조미를 극대화 시키기 위해 리듬, 반복, 점진 기법에 의한 운동감, 불균형 - 비대칭 - 절개에 의한 균형성, 다변형 - 개 방 - 유동 등의 가변성, 유추 · 해석에 의한 상징성과 그 외 독창성, 심미성, 형식주의 등의 구축원리를 표 현방식으로 사용하는 것으로 나타났다.

\section{Conclusion}

본 연구는 최근 패션 디자인 분야에서 의복 실루 엣 및 디테일의 형태적 변형을 통해 나타나는 독창 적이며, 아방가르드한 패션의 변화양상을 표명하기 위해 형식적 모델로 ‘구조적 디자인’을 설정하였다.

〈Table 5〉 The structural aesthetics of Santiago Calatrava and modern structural fashion design

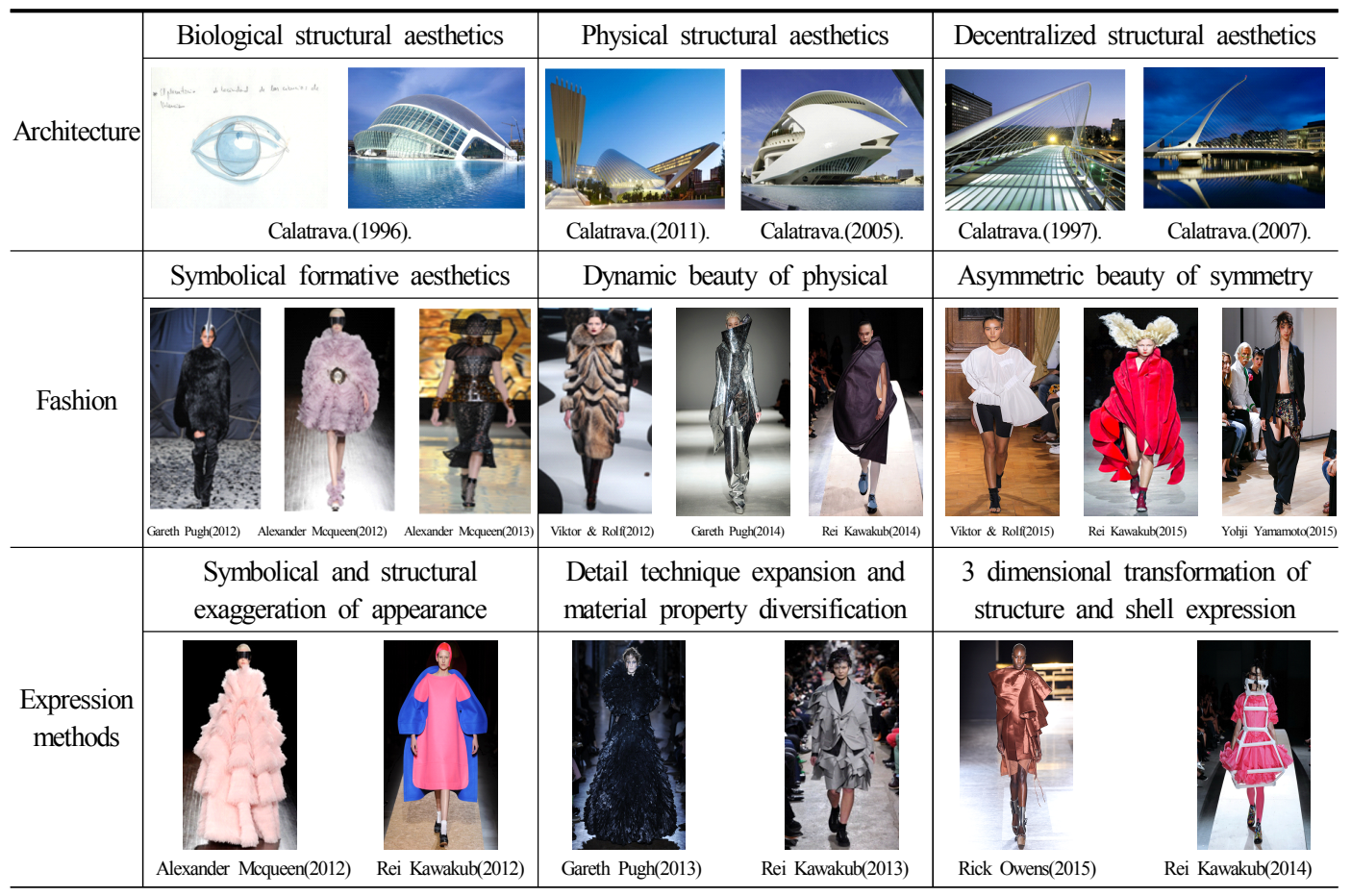


자연에서 영감을 얻어 새나 생물체의 골격, 인간의 다양한 움직임 등을 구조미의 모델로 하여, 기능과 형태라는 복합적 요소를 단순하지만 독창적인 구조 와 공간의 특성으로 표현하는 산티아고 칼라뜨라바 의 건축특성을 중심으로 구조미 표현방법과 그러한 효과를 위해 사용된 구축방식을 고찰함으로써 현대 구조적 패션디자인에 표현된 구조미의 표현방법과 그러한 효과를 극대화하기 위한 표현방식(구축방식) 을 분석하였다.

연구결과를 종합해 보면, 산티아고 칼라뜨라바 건축 디자인의 구조미 표현은 상징적인 유추와 해 석을 통한 생물학적 구조미, 시각적인 강조와 역동 성 가변성에 의한 물리학적 구조미, 균형과 불균형 사이에서 균형쪽으로 전이되는 탈중심적 구조미로 나타났다.

칼라뜨라바 건축의 구조미와 구조적 패션디자인 의 개념적 특성을 중심으로 분석한 패션에 나타난 구조미는 1) 상징적인 유추와 해석을 통한 미적표현 인 상징적 조형미, 2) 시각적인 강조와 역동성에 의 한 표현인 물리적 역동미, 3) 균형과 불균형 사이의 경계에서 균형쪽으로 전이되는 표현으로의 비대칭 적 균형미로 요약할 수 있다.

또한 구조미를 극대화하는 표현방법으로는 1) 외 관형태의 상징적, 구조적 과장, 2) 디테일 기법의 확 장과 재료물성의 다양화, 3) 구조와 외피표현의 입 체적 변형 등의 표현방법을 통해 예술적 심미성의 확보함과 동시에 기존의 형태와 양식을 파괴하고, 새 로운 독창적 형태로 구성함으로써 구조미의 효과를 표현한 것으로 나타났다.

구조적 패션에 있어서 건축적 조형성은 패션의 구조미를 극대화시키기 위해 리듬, 반복, 점진 기법 에 의한 운동감, 불균형, 비대칭, 절개에 의한 균형 성, 다변형, 개방, 유동 등의 가변성, 유추, 해석에 의한 상징성과 그 외 독창성, 심미성, 형식주의 등의 구축원리를 표현방식으로 사용하는 것으로 나타났다.

산티아고 칼라뜨라바의 디자인관은 디자인의 요 소와 원리를 구조적 구조체계로 독특하게 활용하여 구조체계의 디테일 표현방법과 구축방식을 통해 구 조적 디자인을 극대화시키고 있으며, 디자인의 오랜 과제인 기능과 형태라는 양 요소를 통합적으로 구 축하여 새로운 합리성을 구조체계로 제시하고 있다.
이러한 연구는 패션영역뿐만 아니라, 현대디자인에 있어서 디자이너들이 궁극적으로 해결하고자 노력 하는 부분인 예술과 기술, 디자인과 구조의 관계를 상호 완결적으로 해결하면서 표현성과 합리성을 동 시에 성취할 수 있는 디자인 지침으로서 시사하는 바 가 있다고 하겠다. 또한 이를 통해 끊임없이 독창적인 새로운 룩을 지향하는 현대패션에 있어서 디자인의 발상과 전개에 대한 이해를 높이고 표현 가능성을 확대시키는데 기여할 수 있을 것으로 기대한다.

\section{References}

Alexander McQueen. (n.d.a). Fall 2012 Ready-toWear Alexander McQueen. Style.com, Retrieved December 28, 2014 from http://www.style.com/ fashion-shows/fall-2012-ready-to-wear/alexandermcqueen\#collection

Alexander McQueen. (n.d.b). Fall 2012 Ready-to-Wear Alexander McQueen. Style.com, Retrieved December 28, 2014 from http://www.style.com/fashionshows/fall-2012-ready-to-wear/alexander-mcquee $\mathrm{n} \#$ collection

Alexander McQueen. (n.d.c). Spring 2013 Ready-toWear Alexander McQueen. Style.com, Retrieved January 3, 2015 from http://www.style.com/fashionshows/spring-2013-ready-to-wear/alexander-mcq ueen\#collection

Borson, B. (2010, August 10). Dallas and a Calatrava Bridge - we have one. Life of an Architect, Retrieved December 14, 2014 from http://www. lifeofanarchitect.com/dallas-and-a-calatrava-bridg e-we-have-one

Cho, Y. K. (2011). A study on the modern fashion design that adopted the formative characteristics of Jaha Hadid's architecture. Unpublished master's thesis, Ewha Womans University, Seoul, Korea.

Choi, K. H. (2013). A study on structural design in Sandra Backlund collections. Journal of the Korean Society of Fashion Design, 13(3), 157-174.

Choi, K. W. (2011, March 21). 패션 디자이너는 고 객 사랑을 먹고 큰다 [Fashion designers have grown 
to love customers]. Fashion Insight, Retrieved March 25, 2015, from http:/www.fi.co.kr/main/ view.asp?SectionStr $=$ Series $\&$ SectionSub $=49 \& i d x$ $=35456$

Comme des Garçons. (n.d.a). Fall 2012 Ready-toWear Comme des Garçons. Style.com, Retrieved December 28, 2014 from http://www.style.com/ fashion-shows/fall-2012-ready-to-wear/comme-de s-garcons\#collection

Comme des Garçons. (n.d.b). Fall 2013 Ready-toWear Comme des Garçons. Style.com, Retrieved January 3, 2015 from http:/www.style.com/fashionshows/fall-2013-ready-to-wear/comme-des-garco ns\#collection

Comme des Garçons. (n.d.c). Spring 2014 Ready-toWear Comme des Garçons. Style.com, Retrieved January 16, 2015 from http:/www.style.com/fashionshows/spring-2014-ready-to-wear/comme-des-gar cons\#collection

Comme des Garçons. (n.d.d). Spring 2014 Ready-toWear Comme des Garçons. Style.com, Retrieved January 16, 2015 from http://www.style.com/fashionshows/spring-2014-ready-to-wear/comme-des-gar cons\#collection

Comme des Garçons. (n.d.e). Spring 2015 Ready-toWear Comme des Garçons. Style.com, Retrieved January 17, 2015 from http://www.style.com/fashionshows/spring-2015-ready-to-wear/comme-des-gar cons\#collection

Gareth Pugh. (n.d.a). Fall 2012 Ready-to-Wear Gareth Pugh. Style.com, Retrieved December 28, 2014 from http:/www.style.com/fashion-shows/fall-2012ready-to-wear/gareth-pugh\#collection

Gareth Pugh. (n.d.b). Fall 2013 Ready-to-Wear Gareth Pugh. Style.com, Retrieved January 3, 2015 from http://www.style.com/fashion-shows/fall-2013-rea dy-to-wear/gareth-pugh\#collection

Gareth Pugh. (n.d.c). Fall 2014 Ready-to-Wear Gareth Pugh. Style.com, Retrieved January 16, 2015 from http://www.style.com/fashion-shows/fall-2014-rea dy-to-wear/gareth-pugh\#collection
Im, S. M. (2015). A study on modern fashion design applying artifactual characteristics in the architecture by Oscar Niemeyer. Unpublished master's thesis, Ewha Womans University, Seoul, Korea.

Kam, J. H. (2009). A study on the structural aesthetics in architecture of the Santiago Calatrava. Unpublished master's thesis, Changwon University, Gyeongsangnam-do, Korea.

Kim, B. M.(2012). The architectural unstructured space expressed in the fashion design of Alexander McQueen. Unpublished master's thesis, Tongmyong University, Busan, Korea.

Kim, J. M. (2012). A study on the style through analysis of design elements of Rick Owens' works. Unpublished master's thesis, Kyunghee University, Gyeonggi-do, Korea.

Kim, S. I. (2012). A study on structural design in modern fashion. Unpublished master's thesis, Kyunghee University, Gyeonggi-do, Korea.

Kim, Y. K. (2009). A study on the characteristic of modern fashion reflecting architectural molding. Journal of the Korean Society of Design Culture, 15(4), 97-107

Milwaukee Art Museum. (n.d). Quadracci Pavilion. Milwaukee Art Museum, Retrieved December 17, 2014 from http://mam.org/info/details/quadracci. php

Na, H. S. (2008). Aesthetic characteristics of hightech fashion through Hussein Chalayan's works after 2000. Journal of the Korea Fashion \& Costume Design Association, 10(2), 27-38.

Na, M. J. (2010). A study of fashion design applied by the image of bird shown in the Santiago Calatrava's works. Unpublished master's thesis, Ewha Womans University, Seoul, Korea.

Park, S. J. (2012). Functional minimalism in fashion: In relationship with architecture. Unpublished master's thesis, Sungkyunkwan University, Seoul, Korea.

Rick Owens. (n.d.). Spring 2015 Ready-to-Wear Rick Owens. Style.com, Retrieved January 17, 2015 
from http://www.style.com/fashion-shows/spring2015-ready-to-wear/rick-owens\#collection

Rottenbury K., Becan, R., \& Long, K. (2006). 현대 건축가 111 인 [Architects today] (J. S. Lee, Trans.). Seoul: Kukje. (Original work published 2004).

Santiago Calatrava. (n.d.a). Alamillo Bridge \& Cartuja Viaduct. Santiago Calatrava, Retrieved December 13, 2014 from http:/www.calatrava.com/projects/ alamillo-bridge-cartuja-viaduct-seville.html

Santiago Calatrava. (n.d.b). Bach de Roda - Felipe II Bridge. Santiago Calatrava, Retrieved December 17, 2014 from http:/www.calatrava.com/projects/ bach-de-roda-felipe-ii-bridge-barcelona.html

Santiago Calatrava. (n.d.c). Bridge of Strings (Light Rail Train). Santiago Calatrava, Retrieved December 18, 2014 from http://www.calatrava.com/projects/ bridge-of-strings-light-rail-train-jerusalem.html

Santiago Calatrava. (n.d.d). Ciudad de las Artes y de las Ciencias. Santiago Calatrava, Retrieved December 13, 2014, from http://www.calatrava.com/ projects/ciudad-de-las-artes-y-de-las-ciencias-vale ncia.html

Santiago Calatrava. (n.d.e). Stadelhofen Station. Santiago Calatrava, Retrieved December 13, 2014 from http://www.calatrava.com/projects/stadelhofen-sta tion-zuerich.html

Santiago Calatrava. (n.d.f). Turning Torso. Santiago Calatrava, Retrieved December 18, 2014 from http://www.calatrava.com/projects/turning-torsomalmoe.html

Shin, H. J. (2008). A study on fashion design with applying formative elements of Antoni Gaudi.
Unpublished master's thesis, Ewha Womans University, Seoul, Korea.

Sohn, S. H. (2013). A study on modern fashion design applying artifactual characteristics in the architecture by Peter Eisenman. Unpublished master's thesis, Ewha Womans University, Seoul, Korea.

Structure. (n.d.a). In Naver Dictionary. Retrieved March 23, 2015, from http://krdic.naver.com/ detail.nhn?docid $=4317800$

Structure. (n.d.b). In Wikipedia. Retrieved March 23, 2015, from http://ko.wikipedia.org/wiki/\%EA\% $\mathrm{B} 5 \% \mathrm{AC} \% \mathrm{EC} \% \mathrm{~A} 1 \% \mathrm{~B} 0$

Sung, H. J. (2005). A study on a costume design appling high-tech architecture: Focused on Santiago Calatrava's work. Unpublished master's thesis, Keimyung University, Daegu, Korea.

Viktor \& Rolf. (n.d.a). Fall 2012 Ready-to-Wear Viktor \& Rolf. Style.com, Retrieved December 28, 2014 from http://www.style.com/fashion-shows/ fall-2012-ready-to-wear/viktor-rolf\#collection

Viktor \& Rolf. (n.d.b). Spring 2015 Ready-to-Wear Viktor \& Rolf. Style.com, Retrieved January 17, 2015 from http://www.style.com/fashion-shows/ spring-2015 - ready-to-wear/viktor-rolf\#collection

Yohji Yamamoto. (n.d.). Spring 2015 Ready-to-Wear Yohji Yamamoto. Style.com, Retrieved January 13, 2015 from http:/www.style.com/fashion-shows/ spring-2015-ready-to-wear/yohji-yamamoto\#colle ction

Yoon, J. A. (2014). The structure and characteristics of modular system expressed in contemporary fashion design. Unpublished doctoral dissertation, Hanyang University, Seoul, Korea. 